\title{
PENGEMBANGAN PERANGKAT PEMBELAJARAN MODEL GUIDED DISCOVERY BERBASIS KEGIATAN BIOMONITORING PARTISIPATIF UNTUK MENINGKATKAN KETERAMPILAN BERPIKIR TINGKAT TINGGI PADA MATERI PENCEMARAN AIR
}

\author{
Mirna Yunik Citriana ${ }^{1)}$, Soetjipto ${ }^{2)}$, Raharjo ${ }^{3)}$ \\ ${ }^{1)}$ Mahasiswa Program Studi Pendidikan Sains, Program Pascasarjana Universitas Negeri Surabaya \\ ${ }^{2)}$, 3)Dosen Pascasarjana Prodi Pendidikan Sains Univesrtitas Negeri Surabaya
}

\begin{abstract}
This research is conducted based on the unavailibility of the planning, process, and evaluation of learning which refers to the higher-order thinking skills as literacy needed to facilitate in twenty-first century science teaching and learning. The purpose of the research is to develop a model of guided discovery learning through participatory biomonitoring activities to improve students' higher-order thinking skills on water pollution materials. The type of this research is development research which implemented in a grade VII at SMP Negeri 1 Deket Lamongan. The development of learning on package in the research carried out using 4-D model of Thiagarajan, wich consist of stages of development, namely: define, design, develop, without using disseminate stage. The result data from this research are: (1) the valid learning syllabus, lesson plans, student teaching materials, student worksheets, tests and assessment instruments, (2) the legibility of teaching materials and student worksheets show the excellent category, (3) feasibility of lesson plan syntax was considered good and reliable, (4) the understanding of the learning concept has been completed individually, classically, and indicators, (5) higher-order thinking skills of students' can improved (6) the students' activity showed successful and reliable, and (7) the students' response to the learning activities were interested in they feel something new, easy and interesting in using the model in teaching learning process. Based on the findings of this research it can be concluded that the matterial learning development of guided discovery models through participatory biomonitoring activities has feasibility, practically, and effectiveness of the good category to use in and it could improve students higher-order thinking skills in the material of water pollution.
\end{abstract}

Keywords: Learning Package Development, Guided Discovery Models, Participatory Biomonitoring Activities, Higher- Order Thinking Skills, Water Pollution

\begin{abstract}
Abstrak: Penelitian ini dilatarbelakangi belum tersedianya perencanaan, proses, dan evaluasi pembelajaran yang merujuk pada keterampilan berpikir tingkat tinggi sebagai literasi yang perlu dilatihkan dalam kegiatan pembelajaran sains abad dua puluh satu. Tujuan penelitian yaitu mengembangkan perangkat pembelajaran model guided discovery berbasis kegiatan biomonitoring partisipatif untuk meningkatkan keterampilan berpikir tingkat tinggi siswa pada materi pencemaran air. Jenis penelitian adalah penelitian pengembangan yang diimplementasikan di kelas VII di SMPN 1 Deket Lamongan. Pengembangan perangkat pembelajaran dalam penelitian ini menggunakan Model 4-D dari Thiagarajan, yang terdiri dari tahap-tahap: define, design, develop, tanpa menggunakan tahap disseminate. Data hasil penelitian adalah: (1) Silabus Pembelajaran, RPP, Materi Ajar Siswa, LKS, dan Instrumen Penilaian Tes memperoleh kategori valid, (2) Pemahaman siswa terhadap Materi Ajar Siswa dan LKS menunjukkan kategori sangat baik, (3) keterlaksanaan sintaks pada RPP dinilai baik dan reliabel, (4) secara individual dan indikator, hasil belajar pemahaman konsep telah tuntas, (5) keterampilan berpikir tingkat tinggi siswa meningkat (6) aktivitas siswa dinyatakan baik dan reliabel, dan (7) respon siswa terhadap komponen-komponen pembelajaran adalah merasa ketertarikan, merasakan kebaharuan, kemudahan dan menyatakan keberminatan terhadap kegiatan pembelajaran. Berdasarkan temuan pada penelitian ini dapat disimpulkan bahwa pengembangan perangkat pembelajaran model guided discovery berbasis kegiatan biomonitoring partisipatif memiliki kelayakan, kepraktisan, dan efektivitas yang baik sehingga dapat digunakan dan dapat meningkatkan keterampilan berpikir tingkat tinggi siswa pada materi pencemaran air.
\end{abstract}

Kata kunci: Pengembangan Perangkat Pembelajaran, Model Guided Discovery, Biomonitoring Partisipatif, Keterampilan Berpikir Tingkat Tinggi, Pencemaran Air

\section{PENDAhUluan}

Abad kedua puluh satu ditandai dengan perkembangan sains dan teknologi yang sangat pesat. Perkembangan ini membuat tuntutan baru di masyarakat, di mana literasi saintifik merupakan bagian penting dalam kehidupan modern. Guru harus dapat mempersiapkan siswa untuk dunia yang sangat berbeda dari di mana guru dibesarkan. Abad kedua puluh satu membutuhkan siswa yang menguasai ilmu pengetahuan dan teknologi untuk dapat memahami dunia yang 
berubah dengan cepat (Carin, 1993a; Carin, 1993b). Dapat dikatakan bahwa melalui dunia pendidikan, guru dituntut untuk membekali siswa dengan pengetahuan dan keterampilan yang dapat memberdayakan siswa untuk masa depannya, serta dapat menjawab setiap permasalahan yang timbul akibat tantangan perkembangan jaman.

Permendiknas RI No. 41 tahun 2007 tentang Standar Proses menjelaskan bahwa visi pendidikan nasional adalah terwujudnya sistem pendidikan sebagai pranata sosial yang kuat dan berwibawa untuk memberdayakan semua warga negara Indonesia berkembang menjadi manusia yang berkualitas sehingga mampu dan proaktif menjawab tantangan zaman yang selalu berubah.

Selanjutnya Peraturan Pemerintah No. 19 tahun 2005 menjelaskan bahwa dengan pendidikan yang ada, siswa diharapkan (a) memiliki dasar kecerdasan, pengetahuan, kepribadian, akhlak mulia, serta keterampilan untuk hidup mandiri dan mengikuti pendidikan lebih lanjut (b) memiliki kecakapan hidup yang mencakup kecakapan pribadi, kecakapan sosial, kecakapan akademik, dan kecakapan vakasional. Untuk itu proses pembelajaran pada satuan pendidikan diselenggarakan secara interaktif, inspiratif, menyenangkan, menantang, memotivasi peserta didik untuk berpartisipasi aktif, serta memberikan ruang yang cukup bagi prakarsa, kreativitas, dan kemandirian sesuai dengan bakat, minat, dan perkembangan fisik serta psikologis peserta didik.

Guru saat ini harus berpandangan bahwa pendekatan dalam pembelajaran sains pada dasarnya harus pararel dengan prosedur dan sikap ilmiah yang digunakan. Pendekatan minds-on dan hands-on mengingatkan para guru bahwa pendidikan sains yang efektif berarti lebih dari sekadar menyajikan informasi bagi siswa untuk belajar atau sains sebagai alat bagi siswa untuk menangani sesuatu. Guru juga harus menyediakan kegiatan yang direncanakan dan umpan balik instruksional untuk siswa karena pada dasarnya siswa juga memikirkan dan menafsirkan pengalaman sains tersebut (Carin, 1993a; Carin, 1993b).

Hakekat sains merupakan suatu kesatuan produk, proses, dan sikap, untuk mencapai tujuan pembelajaran. Untuk itu pembelajaran sains harus mengacu pada ketiga aspek esensial, yaitu: (1) pengetahuan, berupa pemahaman konsep, hukum, dan teori serta penerapannya; (2) kemampuan melakukan proses, yaitu proses pemecahan masalah melalui metode ilmiah yang meliputi penyusunan hipotesis, perancangan eksperimen atau percobaan, evaluasi, pengukuran, dan penarikan kesimpulan; (3) sikap keilmuan, antara lain berupa kecenderungan keilmuan, berpikir kritis, berpikir analitis, tanggung jawab, perhatian pada masalah-masalah sains, dan penghargaan pada hal-hal yang bersifat sains (Toharuddin et al., 2011).

Tidak ada pembahasan tentang pembelajaran yang sempurna tanpa memasukkan pembahasan tentang berpikir. Semakin berkembang keterampilan berpikir siswa, semakin intens siswa akan belajar. Pemahaman yang mendalam tentang suatu materi pembelajaran harus menekankan pada keterampilan berpikir (Eggen \& Kauchak, 2012). Keterampilan berpikir yang dikembangkan sebaiknya adalah kemampuan berpikir yang dapat menjangkau keterampilan berpikir tingkat tinggi yang dikenal dengan higher order thinking skill (HOTS). Keterampilan berpikir tingkat tinggi merupakan salah satu keterampilan berpikir esensial yang secara kompleks meliputi keterampilan pemecahan masalah (problem solving), keterampilan pengambilan keputusan, keterampilan berpikir kritis (critical thinking), dan keterampilan berpikir kreatif.

Observasi tentang kegiatan pembelajaran yang meliputi perencanaan, proses, hasil dan evaluasi yang dilakukan penulis di SMP Negeri 1 Deket Lamongan menunjukkan bahwa keterampilan berpikir tingkat tinggi sebagai salah satu aspek penting yang perlu ditingkatkan kepada siswa dalam kegiatan pembelajaran sains pada abad kedua puluh satu, kurang mendapat perhatian guru.

Fakta dari sisi guru dibuktikan dengan beberapa hal: (1) perencanaan perangkat pembelajaran yang dikembangkan oleh guru belum ada yang mengacu pada model pembelajaran inovatif, yang dapat meningkatkan pembelajaran dan menstimulasi motivasi siswa, (2) proses pelaksanaan pembelajaran sains belum mengarah pada upaya memaksimalkan kegiatan minds-on dan hands-on yang dapat meningkatkan keterampilan berpikir tingkat tinggi pada siswa, (3) hasil dan evaluasi pembelajaran yang dilakukan guru lebih menekankan pada aspek produk terutama untuk ranah kognitif, dan kurang memperhatikan aspek proses, aspek kinerja dan ranah afektif siswa.

Fakta dari sisi siswa dibuktikan dengan beberapa hal: (1) siswa lebih memiliki keterampilan menghafal (meniru pasif) daripada keterampilan pemecahan masalah (problem solving), keterampilan pengambilan keputusan, keterampilan berpikir kritis (critical thinking), dan keterampilan berpikir kreatif, (2) siswa kurang berani dalam berdiskusi, mengungkapkan gagasan atau pendapat siswa kepada siswa, maupun siswa kepada guru.

Guru yang efektif harus dapat memilih pembelajaran dengan model yang dapat meningkatkan pembelajaran dan menstimulasi motivasi siswa (Arends, 2007). Pembelajaran model guided discovery adalah salah satu yang efektif untuk mendorong keterlibatan dan motivasi siswa seraya membantu siswa 
mendapatkan pemahaman mendalam tentang suatu topik dengan materi yang spesifik dan teridentifikasi dengan jelas, baik sebagai konsep maupun sebagai generalisasi (Eggen \& Kauchak, 2012). Pembelajaran model guided discovery membuat siswa belajar sains dan teknologi dengan solid, melibatkan siswa dalam tindakan eksplorasi penyelidikan, mengkonstruksi makna dari temuannya, mengusulkan penjelasan tentative dan solutif, mengeksplorasi konsep kembali, dan kemudian mengevaluasi konsep yang mengacu pada hidup siswa sendiri (Carin, 1993a).

Belajar tentang suatu konsep lebih dari mengklasifikasikan objek dan membentuk berbagai kategori. Belajar konsep melibatkan proses yang dapat mengkonstruksi pengetahuan dan mengorganisasikan informasi menjadi struktur yang komprehensif dan kompleks. Pengetahuan konseptual merupakan salah satu tipe pengetahuan yang utama yang memungkinkan siswa untuk menjadi sadar akan skemata yang sudah dimilikinya dan membantu siswa mengembangkan konsep-konsep baru dan mereformulasikan keterampilan berpikir yang sudah ada (Arends, 2007).

Penulis memilih alternatif pembelajaran model guided discovery berbasis biomonitoring partisipatif terhadap pembelajaran sains pada materi pencemaran air. Materi pencemaran air yang meliputi tentang banyaknya permasalahan pencemaran air di sekitar, penyebab pencemaran air dan solusinya, berbagai indikator pencemaran air, merupakan satu materi yang sangat krusial yang harus disampaikan kepada siswa dalam pembelajaran dengan model tepat. Bruner dalam Dahar, 1988 menyatakan bahwa dengan guided discovery, siswa dapat berusaha untuk mencari penyelesaian masalah dengan pengetahuan yang menyertainya, sehingga menghasilkan pengetahuan yang benar-benar bermakna.

Biomonitoring partisipatif merupakan satu metode dalam kegiatan pemantauan kualitas lingkungan dengan menggunakan indikator biologi, dengan melibatkan peran serta masyarakat. Metode ini dikenal juga dengan istilah Biotilik, yang berarti memanfaatkan makhluk hidup (parameter biologi) untuk memantau lingkungan dan telah ditetapkan sebagai parameter kunci dalam pemantauan kualitas air, disamping parameter fisika dan kimia (Rini \& Resh, 2011). Kegiatan biomonitoring partisipatif dengan menggunakan hewan invertebrata makro sebagai indikator biologi untuk memantau kualitas lingkungan di suatu perairan mempunyai karakteristik yang mudah, murah, dan memberi banyak manfaat dalam hal perencanaan, pelaksanaan, dan evaluasi (Mason, 1991; Odum, 1993; Rosenberg \& Resh, 1993; Sudaryanti, 1997; Trihadiningrum, 1997).

Beberapa penelitian telah dilakukan tentang pembelajaran model guided discovery. Rahmawati,
2012, (Pengembangan Perangkat Pembelajaran dengan Metode Pembelajaran Penemuan Terbimbing: Guided Discovery untuk Melatih Keterampilan Berpikir Kritis Siswa SMP), menunjukkan bahwa pembelajaran IP A Fisika dengan metode guided discovery dapat melatih keterampilan berpikir kritis siswa SMP serta mampu menuntaskan hasil belajar kognitif siswa. Nasihah, M., 2012, (Pengembangan Perangkat Pembelajaran Pendidikan Lingkungan Hidup Berorientasi Penemuan Terbimbing; Guided Discovery di FKIP Unisda Lamongan), menunjukkan bahwa hasil belajar mahasiswa dapat meningkat dengan metode guided discovery.

Perangkat pembelajaran merupakan salah satu faktor penunjang keberhasilan proses pembelajaran yang dapat membantu mempermudah guru dalam persiapan, pelaksanaan, dan evaluasi kegiatan pembelajaran. Sejumlah strategi disiapkan untuk mendorong terciptanya lingkungan belajar yang kondusif yang sesuai dengan kebutuhan siswa. Untuk itu penulis termotivasi mengembangkan perangkat pembelajaran model guided discovery berbasis kegiatan biomonitoring partisipatif untuk meningkatkan keterampilan berpikir tingkat tinggi pada materi pencemaran air. Kegiatan penelitian dimulai dari tahap analisis materi kurikulum, dilanjutkan penyusunan perangkat pembelajaran, kemudian dilakukan validasi ahli, dan diujicobakan di kelas yang telah ditentukan.

\section{METODE PENELITIAN}

Penelitian ini merupakan penelitian pengembangan (development research). Produk yang dikembangkan berupa perangkat pembelajaran model guided discovery berbasis kegiatan biomonitoring partisipatif untuk meningkatkan keterampilan berpikir tingkat tinggi.

Model pengembangan yang digunakan mengacu pada model 4-D (four D models), yaitu: (1) define (pendefinisian), (2) perangkat design (perancangan), (3) develop (pengembangan), dan (4) disseminate (penyebaran). Tahap disseminate tidak dilaksanakan, karena hasil pengembangan tidak diterapkan di sekolah lain (Semmel \& Semmel dalam Ibrahim, 2003).

Rancangan penelitian pada Uji Coba I dan Uji Coba II dilakukan dengan menerapkan model One Group Pretest-Posttest Design, dengan menggunakan satu kelompok subyek dengan pola sebagai berikut.

$$
\mathrm{U}_{1} \times \mathrm{U}_{2}
$$




\section{Keterangan:}

$\mathrm{U}_{1}=\mathrm{Uji}$ awal (pretest) untuk mengetahui kemampuan awal siswa sebelum penerapan perangkat pembelajaran.

$\mathrm{x}=$ Perlakuan dengan pembelajaran model guided discovery berbasis kegiatan biomonitoring partisipatif.

$\mathrm{U}_{2}=\mathrm{Uji}$ akhir (postest) untuk mengetahui hasil belajar siswa setelah penerapan perangkat pembelajaran.

Perbedaan antara U1 dan U2 (n-gain score) diasumsikan merupakan efek dari perlakuan yang diberikan.

Variabel-variabel yang diamati dalam penelitian ini meliputi: (1) kelayakan perangkat pembelajaran, ditinjau dari aspek berikut validitas dan tingkat pemahaman siswa, (2) kepraktisan Rencana Pelaksanaan Pembelajaran (RPP), (3) keefektifan penerapan pembelajaran, ditinjau dari aspek ketercapaian indikator hasil belajar pemahaman konsep, peningkatan keterampilan berpikir tingkat tinggi siswa, aktivitas siswa dan guru, dan respon siswa, (4) kendalakendala yang ditemukan dalam pelaksanaan pembelajaran.

Instrumen yang digunakan dalam penelitian ini meliputi: (1) Lembar Pengamatan Kelayakan Perangkat Pembelajaran, meliputi: Lembar Validasi dan Lembar Tingkat Pemahaman Siswa, (2) Lembar Pengamatan Kepraktisan Rencana Pelaksanaan Pembelajaran (RPP), (3) Lembar Keefektifan Penerapan Pembelajaran, meliputi: Lembar Instrumen Penilaian Tes Pemahaman Konsep, Lembar Instrumen Penilaian Tes Keterampilan Berpikir Tingkat Tinggi, Lembar Pengamatan Aktivitas Siswa, dan Angket Respon Siswa, (4) Lembar Pengamatan Kendala-kendala.

\section{HASIL PENELITIAN DAN DISKUSI}

Penelitian ini dilaksanakan di SMPN 1 Deket Lamongan, Jawa Timur, di kelas 7B dan 7G Tahun Pelajaran 2013/2014. Hasil dan diskusi dari ketiga tahap penelitian tersebut dipaparkan sebagai berikut.

\section{A. Kelayakan Perangkat Pembelajaran yang Dikembangkan}

Kelayakan perangkat pembelajaran terdiri dari validitas perangkat pembelajaran oleh 3 orang pakar yang kompeten di bidang pendidikan dan tingkat pemahaman siswa di Kelas VII B dan Kelas VII G terhadap perangkat pembelajaran.

1. Validitas Perangkat Pembelajaran

Perangkat pembelajaran yang dikembangkan meliputi (1) Silabus Pembelajaran, (2) Rencana Pelaksanaan Pembelajaran (RPP), (3) Materi Ajar Siswa, (4) Lembar Kegiatan Siswa (LKS), dan (5)
Instrumen Penilaian Tes. Hasil validasi seperti Tabel 1 berikut.

Tabel 1. Hasil Validasi Perangkat

\begin{tabular}{|c|l|c|}
\hline No. & \multicolumn{1}{|c|}{ Nama Perangkat } & Kriteria \\
\hline 1. & Silabus & Baik \\
\hline 2. & $\begin{array}{l}\text { Rencana Pelaksanaan Pembelajaran } \\
\text { (RPP) }\end{array}$ & Baik \\
\hline 3. & Materi Ajar Siswa & Baik \\
\hline 4. & Lembar Kegiatan Siswa (LKS) & Baik \\
\hline 5. & Instrumen Penilaian Tes & Valid \\
\hline
\end{tabular}

Hasil penilaian validator menunjukkan bahwa semua perangkat pembelajaran yang telah dikembangkan layak untuk diimplementasikan dalam kelas ujicoba.

2. Tingkat Pemahaman Siswa terhadap Perangkat Pembelajaran

Tingkat pemahaman siswa terhadap perangkat pembelajaran disajikan seperti Tabel 2 berikut.

Tabel 2. Hasil Pemahaman Siswa

\begin{tabular}{|l|l|l|l|l|}
\hline No. & \multicolumn{2}{|c|}{ Aspek Pemahaman } & \multicolumn{2}{l|}{$\begin{array}{l}\text { Rata-Rata } \\
\text { Persentase } \\
\text { Respon Siswa } \\
\text { (\%) }\end{array}$} \\
\hline 1. & Tentang komponen: & T & TT \\
\hline & a. & Isi dari Materi Ajar Siswa & 87 & 13 \\
\hline & b. & Isi dari LKS & 92 & 8 \\
\hline & c. & $\begin{array}{l}\text { Penampilan/tata letak/lay out } \\
\text { dari Materi Ajar Siswa }\end{array}$ & 99 & 1 \\
\hline d. & $\begin{array}{l}\text { Penampilan/tata letak/lay } \\
\text { out dari LKS }\end{array}$ & 99 & 1 \\
\hline 2. & $\begin{array}{l}\text { Kemudahan dalam memahami } \\
\text { komponen-komponen: }\end{array}$ & M & S \\
\hline & a. & $\begin{array}{l}\text { Kata/kalimat pada Materi } \\
\text { Ajar Siswa }\end{array}$ & 90 & 10 \\
\hline & b. & Kata/kalimat pada LKS & 90 & 10 \\
\hline & c. & $\begin{array}{l}\text { Gambar/ilustrasi pada } \\
\text { Materi Ajar Siswa }\end{array}$ & 99 & 1 \\
\hline & d. & Gambar/ilustrasi pada LKS & 97 & 3 \\
\hline
\end{tabular}

Keterangan:

$$
\begin{array}{ll}
\mathrm{T}=\text { tertarik } & \mathrm{M}=\text { mudah } \\
\mathrm{TT}=\text { tidak tertarik } & \mathrm{S}=\text { sulit }
\end{array}
$$

Rata-rata hasil pemahaman siswa memperoleh rata-rata yang tinggi, sehingga dapat disimpulkan bahwa Materi Ajar Siswa dan LKS yang dikembangkan layak untuk digunakan dalam kegiatan pembelajaran.

\section{B. Kepraktisan Rencana Pelaksanaan Pembelajaran (RPP) yang Dikembangkan}

Kepraktisan ditinjau dari keterlaksanaan RPP yang dikembangkan. Data keterlaksanaan pembelajaran disajikan dalam Tabel 3 berikut.

Tabel 3. Skor Penilaian Keterlaksanaan RPP

\begin{tabular}{|l|l|l|l|}
\hline No. & $\begin{array}{l}\text { Sintaks } \\
\text { Pembelajaran, } \\
\text { Pengelolaan Waktu, } \\
\text { dan Suasana kelas }\end{array}$ & $\begin{array}{l}\text { Rata-rata Skor } \\
\text { Keterlak- } \\
\text { Sanaan Tiap } \\
\text { RPP }\end{array}$ & $\begin{array}{l}\text { Kriter } \\
\text { ia }\end{array}$ \\
\hline A. & $\begin{array}{l}\text { Fase Pendahuluan } \\
\text { /Apersepsi }\end{array}$ & 3,66 & Baik \\
\hline
\end{tabular}




\begin{tabular}{|l|l|c|c|}
\hline B. & Fase Inti & 3,68 & Baik \\
\hline & 1. Fase Open-ended & 3,68 & Baik \\
\hline & 2. Fase Konvergen & 3,67 & Baik \\
\hline C. & $\begin{array}{l}\text { Fase Penutup } \\
\text { (closure) dan } \\
\text { Penerapan }\end{array}$ & 3,62 & Baik \\
\hline D. & $\begin{array}{l}\text { Pengelolaan waktu } \\
\text { yang baik }\end{array}$ & 3,82 & Baik \\
\hline E. & Suasana kelas & 3,86 & Baik \\
\hline
\end{tabular}

Berdasarkan data yang disajikan pada Tabel 4.7, diketahui bahwa rata-rata persentase keterlaksanaan RPP memperlihatkan hasil yang baik dan dapat memberi gambaran bahwa guru mampu mengajar sesuai langkah pembelajaran dengan menggunakan LKS penunjang pada materi pencemaran air yang bertujuan untuk mengukur ketercapaian indikator hasil belajar pemahaman konsep dan meningkatkan keterampilan berpikir tingkat tinggi siswa. Keterlaksanaan sintaks pembelajaran model guided discovery mengacu pada fase menurut Eggen \& Kauchak (2011) dan Jacobsen, et al. (2009), yaitu fase pendahuluan atau apersepsi, fase inti (open-ended dan konvergen), fase penutup (closure) dan penerapan, sehingga dapat disimpulkan bahwa RPP yang dikembangkan telah memenuhi kriteria kepraktisan, sehingga layak untuk digunakan dan diimplementasikan lebih lanjut pada kegiatan pembelajaran IPA di kelas VII.

\section{Keefektifan Penerapan Pembelajaran}

1. Ketercapaian Indikator Hasil Belajar Pemahaman Konsep

Ketercapaian indikator hasil belajar pemahaman konsep diukur dari ketuntasan individu dan ketuntasan indikator pada aspek kognitif. Persentase ketuntasan individu sebelum pembelajaran (pretest) dan sesudah pembelajaran (posttest) ditetapkan berdasarkan kriteria ketuntasan minimal (KKM) SMP Negeri 1 Deket yaitu $\geq 75$. Perbedaan hasil belajar individu pada kegiatan pretest dan posttest dinilai dengan $n$-gain score.

Tabel 4. Persentase Ketuntasan Individu

\begin{tabular}{|l|c|c|c|c|}
\hline \multirow{2}{*}{ Keterangan } & \multicolumn{2}{c|}{ VIIB } & \multicolumn{2}{c|}{ VIIG } \\
\cline { 2 - 5 } & U1 & U2 & U1 & U2 \\
\hline Nilai rata-rata & 39 & 85 & 38 & 84 \\
\hline Nilai minimal & 25 & 75 & 20 & 75 \\
\hline Nilai maksimal & 60 & 100 & 55 & $\begin{array}{c}10 \\
0\end{array}$ \\
\hline Jumlah tidak tuntas & 29 & 0 & 30 & 0 \\
\hline Jumlah tuntas & 0 & 29 & 0 & 30 \\
\hline $\begin{array}{l}\text { Ketuntasan } \\
\text { indikator }\end{array}$ & $0 \%$ & $100 \%$ & $0 \%$ & $\begin{array}{c}10 \\
0 \%\end{array}$ \\
\hline \multicolumn{1}{|c|}{$N$-gain score } & $\begin{array}{l}\text { Sedang }=12 \text { siswa } \\
; \text { Tinggi }=17 \text { siswa }\end{array}$ & $\begin{array}{l}\text { Sedang }=10 \\
\text { siswa ; } \\
\text { Tinggi }=20 \\
\text { siswa }\end{array}$ \\
\hline $\begin{array}{l}\text { Sensitivitas butir } \\
\text { soal }\end{array}$ & $\begin{array}{l}\text { 4 soal } \\
\text { sensitivitasnya } \\
\text { kategori baik }\end{array}$ & $\begin{array}{l}\text { 4 soal } \\
\text { sensitivitasn } \\
\text { ya kategori } \\
\text { baik }\end{array}$ \\
\hline
\end{tabular}

Keterangan:

$$
\begin{array}{ll}
\mathrm{U} 1=\text { Pretest } & \mathrm{T}=\text { Tuntas } \\
\mathrm{U} 2=\text { Posttest } & \mathrm{TT}=\text { Tidak Tuntas }
\end{array}
$$

Analisis pada Tabel 4 menunjukkan bahwa seluruh siswa pada kelas implementasi (29 siswa di Kelas VII B dan 30 siswa di Kelas VII G) yang mengikuti pretest tidak mampu mencapai KKM, sehingga secara individu dinyatakan tidak tuntas. Hasil posttest di Kelas VII B menunjukkan bahwa secara individu keseluruhan sebanyak 29 siswa dinyatakan tuntas; di Kelas VII G menunjukkan bahwa secara individu keseluruhan sebanyak 30 siswa dinyatakan tuntas. Perbedaan hasil belajar pada masing-masing individu yang dilaksanakan sebelum pembelajaran (pretest) dan sesudah pembelajaran (posttest) dinilai dengan $n$-gain score. Kelas VII B memiliki n-gain dengan kriteria sedang sebanyak 12 siswa dan $n$-gain dengan kriteria tinggi sebanyak 17 siswa; selanjutnya Kelas VII G memiliki n-gain dengan kriteria sedang sebanyak 10 siswa dan $n$-gain dengan kriteria tinggi sebanyak 20 siswa.

Pada kegiatan pretest, sebanyak empat soal dari dua indikator yang diujikan kesemuanya tidak tuntas, dan pada kegiatan posttest, kesemua indikator yang diujikan dapat tuntas. Hasil analisis menggambarkan bahwa pembelajaran model guided discovery berbasis kegiatan biomonitoring partisipatif dapat memberikan hasil yang sangat baik, terbukti dengan ketuntasan indikator yang mencapai $100 \%$.

Untuk mengukur seberapa baik butir soal mampu membedakan antara siswa yang telah menerima pembelajaran dengan siswa yang belum menerima pembelajaran, selanjutnya dihitung persentase sensitivitas butir soal. Empat soal pemahaman konsep yang diujikan di dua kelas implementasi, yaitu Kelas VII B dan Kelas VII G, persentase sensitivitasnya diatas 0,30 sehingga mendapat kriteria baik (Grounlund, 1985). Hal ini menunjukkan bahwa hasil belajar pemahaman konsep yang diperoleh siswa merupakan efek dari pembelajaran model guided discovery berbasis kegiatan biomonitoring partisipatif pada materi pencemaran air.

\section{Peningkatan Keterampilan Berpikir Tingkat Tinggi Siswa}

Setelah diberikan pembelajaran model guided discovery berbasis kegiatan biomonitoring partisipatif, secara umum telah terjadi peningkatan keterampilan berpikir tingkat tinggi pada siswa, dengan kriteria sebagai berikut. (a) Keterampilan pemecahan masalah (problem solving), siswa telah dapat 1) mengidentifikasi dan menganalisis permasalahan, 2) menerapkan hasil belajar, 3) mengumpulkan informasi baru, 4) mengorganisasikan dan membandingkan data, 5) 
menganalisis elemen dan hubungannya, 6) mengklarifikasi dan menilai alternatif, 7) merumuskan simpulan atau memilih cara pemecahan (b) keterampilan pengambilan keputusan, siswa telah dapat 1) membuat pertanyaan, 2) mengumpulkan informasi, 3) memilih alternatif yang terbaik dari beberapa pilihan yang ada, (c) keterampilan berpikir kritis (critical thinking), siswa telah mampu 1) mengenal masalah, 2) menemukan cara-cara untuk menangani masalah, 3) mengumpulkan dan menyusun informasi yang diperlukan, 4) menganalisis data, 5) menilai fakta dan mengevaluasi pernyataan, 6) mengenal hubungan logis antara masalah-masalah, 7) menarik simpulan, 8) membuat penilaian yang tepat tentang hal-hal dan kualitas tertentu dalam kehidupan, dan (d) kriteria dari peningkatan keterampilan berpikir kreatif pada siswa adalah 1) penemuan fakta, 2) mengutamakan produksi sesuatu, ide, solusi, misalnya rencana untuk memecahkan suatu masalah, 3) menghasilkan produk sesuatu, misalnya visualisasi.

Peningkatan keterampilan berpikir tingkat tinggi pada siswa diukur dari perbedaan hasil belajar pada kegiatan pretest dan posttest yang meliputi ketuntasan individu dan ketuntasan indikator pada aspek kognitif. Persentase ketuntasan individu pada pretest dan posttest tersaji pada Tabel 5 berikut.

Tabel 5. Persentase Ketuntasan Individu

\begin{tabular}{|l|c|c|c|c|}
\hline \multirow{2}{*}{ Keterangan } & \multicolumn{2}{c|}{ VIIB } & \multicolumn{2}{c|}{ VIIG } \\
\cline { 2 - 5 } & U1 & U2 & U1 & U2 \\
\hline Nilai rata-rata & 30 & 83 & 38 & 82 \\
\hline Nilai minimal & 14 & 62 & 24 & 64 \\
\hline Nilai maksimal & 56 & 94 & 57 & 94 \\
\hline Jumlah tidak tuntas & 29 & 3 & 30 & 3 \\
\hline Jumlah tuntas & 0 & 26 & 0 & 27 \\
\hline $\begin{array}{l}\text { Ketuntasan } \\
\text { indikator }\end{array}$ & $0 \%$ & $100 \%$ & $0 \%$ & $100 \%$ \\
\hline N-gain score & $\begin{array}{l}\text { Sedang }=12 \\
\text { siswa; Tinggi }= \\
17 \text { siswa }\end{array}$ & $\begin{array}{l}\text { Sedang }=10 \\
\text { siswa ; Tinggi } \\
=20 \text { siswa }\end{array}$ \\
\hline $\begin{array}{l}\text { Sensitivitas butir } \\
\text { soal }\end{array}$ & $\begin{array}{l}10 \text { soal } \\
\text { sensitivitasnya } \\
\text { kategori baik }\end{array}$ & $\begin{array}{l}\text { 10 soal } \\
\text { sensitivitasnya } \\
\text { kategori baik }\end{array}$ \\
\hline
\end{tabular}

Keterangan:

$$
\begin{array}{ll}
\mathrm{U} 1=\text { Pretest } & \mathrm{T}=\text { Tuntas } \\
\mathrm{U} 2=\text { Posttest } & \mathrm{TT}=\text { Tidak Tuntas }
\end{array}
$$

Tabel 5 menunjukkan perolehan nilai siswa terhadap soal keterampilan berpikir tingkat tinggi yang ketuntasannya ditetapkan berdasarkan kriteria ketuntasan minimal (KKM) SMP Negeri 1 Deket yaitu $\geq 75$. Analisis menunjukkan bahwa seluruh siswa pada kelas implementasi (29 siswa di Kelas VII B dan 30 siswa di Kelas VII G) yang mengikuti pretest tidak mampu mencapai KKM, sehingga secara individu dinyatakan tidak tuntas. Hasil posttest di Kelas VII B menunjukkan bahwa secara individu sebanyak 26 siswa dinyatakan tuntas, sebanyak 3 siswa dinyatakan tidak tuntas; di Kelas VII G menunjukkan bahwa secara individu sebanyak 27 dinyatakan siswa tuntas, sebanyak 3 siswa dinyatakan tidak tuntas. Siswa yang tidak tuntas selanjutnya diberikan remidi.

Peningkatan keterampilan berpikir tingkat tinggi yang diukur dari perbedaan hasil belajar individu pada kegiatan pretest dan posttest, selanjutnya dinilai dengan $n$-gain score. Sebanyak 12 siswa di Kelas VII B mendapatkan n-gain dengan kriteria sedang dan sebanyak 17 siswa mendapatkan $n$-gain dengan kriteria tinggi; selanjutnya di Kelas VII G sebanyak 10 siswa mendapatkan n-gain dengan kriteria sedang dan sebanyak 20 siswa mendapatkan $n$-gain dengan kriteria tinggi.

Peningkatan keterampilan berpikir tingkat tinggi juga diukur dari perbedaan hasil belajar pada tiap-tiap indikator soal yang diujikan. Pada kegiatan pretest, sebanyak sepuluh indikator yang diujikan tidak tuntas, dan pada kegiatan posttest, kesepuluh indikator yang diujikan tuntas. Hasil analisis menggambarkan bahwa pembelajaran model guided discovery berbasis kegiatan biomonitoring partisipatif memberikan hasil yang sangat baik, terbukti ketuntasan indikator yang mencapai $100 \%$.

Untuk mengukur seberapa baik butir soal mampu membedakan antara siswa yang telah menerima pembelajaran dengan siswa yang belum menerima pembelajaran, selanjutnya digunakan sensitivitas butir soal. Analisis menggambarkan hasil belajar yang diperoleh siswa, yang merupakan efek dari pembelajaran model guided discovery berbasis kegiatan biomonitoring partisipatif yang diimplementasikan di dua kelas, yaitu Kelas VII B dan Kelas VII G. Sepuluh soal yang diujikan, persentase sensitivitasnya diatas 0,30 sehingga mendapat kriteria baik (Grounlund, 1985).

Keterampilan berpikir tingkat tinggi siswa tidak hanya dinilai dari aspek pengetahuan (kognitif) saja. Keterampilan berpikir tingkat tinggi yang merupakan keterampilan kompleks juga dinilai dari keterlibatannya pada proses eksperimen di lapangan dan di laboratorium (aspek kinerja) serta perilaku selama kegiatan pembelajaran (aspek afektif). Persentase hasil tes unjuk kerja pada aspek kinerja, dinilai seperti Tabel 6 berikut.

Tabel 6. Hasil Kegiatan Kinerja Siswa

\begin{tabular}{|c|c|c|c|c|}
\hline No. & $\begin{array}{l}\text { No. } \\
\text { Indik } \\
\text { tor }\end{array}$ & $\begin{array}{l}\text { Aspek yang } \\
\text { Diobservasi }\end{array}$ & $\begin{array}{l}\text { Perse } \\
\text { ntase } \\
\mathbf{( \% )}\end{array}$ & $\begin{array}{l}\text { Kriteri } \\
\text { a }\end{array}$ \\
\hline 1 & 7 & $\begin{array}{l}\text { Persiapan alat dengan } \\
\text { lengkap (boks plastik, } \\
\text { hand net, lup, }\end{array}$ & 100 & $\begin{array}{c}\text { A } \\
\text { (sangat } \\
\text { baik) }\end{array}$ \\
\hline
\end{tabular}




\begin{tabular}{|c|c|c|c|c|}
\hline & & $\begin{array}{l}\text { nampan, pinset, } \\
\text { timba, dan alkohol) } \\
\text { sesuai petunjuk }\end{array}$ & & \\
\hline 2 & 7 & $\begin{array}{ll}\text { Menganalisis } & \text { atribut } \\
\text { jenis-jenis } & \text { hewan } \\
\text { invertebrata } & \text { sesuai } \\
\text { dengan grup } & \text { dalam } \\
\text { panduan bioindikator }\end{array}$ & 85 & $\begin{array}{c}\text { A } \\
\text { (sangat } \\
\text { baik) }\end{array}$ \\
\hline 3 & 8 & $\begin{array}{l}\text { Melakukan kegiatan } \\
\text { pengambilan sampel } \\
\text { sesuai dengan } \\
\text { langkah-langkah } \\
\text { kegiatan }\end{array}$ & 78 & $\begin{array}{c}\text { A } \\
\text { (sangat } \\
\text { baik) }\end{array}$ \\
\hline 4 & 8 & $\begin{array}{l}\text { Melakukan kegiatan } \\
\text { sortir sesuai dengan } \\
\text { langkah-langkah } \\
\text { kegiatan }\end{array}$ & 49 & $\begin{array}{c}\mathrm{C} \\
\text { (cukup) }\end{array}$ \\
\hline 5 & 8 & $\begin{array}{lr}\text { Melakukan } & \text { kegiatan } \\
\text { pengawetan } & \text { sampel } \\
\text { sesuai } & \text { dengan } \\
\text { langkah-langkah } \\
\text { kegiatan }\end{array}$ & 73 & $\begin{array}{c}\text { B } \\
\text { (baik) }\end{array}$ \\
\hline 6 & 11 & $\begin{array}{lr}\text { Mencocokkan } & \text { hewan } \\
\text { invertebrata } & \text { sesuai } \\
\text { dengan } & \text { kunci } \\
\text { identifikasi } & \end{array}$ & 82 & $\begin{array}{c}\text { A } \\
\text { (sangat } \\
\text { baik) }\end{array}$ \\
\hline 7 & 11 & \begin{tabular}{l}
\multicolumn{3}{l}{ Mengidentifikasi } \\
takson dari hewan \\
invertebrata sampai \\
tingkat famili
\end{tabular} & 92 & $\begin{array}{c}\text { A } \\
\text { (sangat } \\
\text { baik) }\end{array}$ \\
\hline 8 & 12 & $\begin{array}{l}\text { Menghitung indeks } \\
\text { biotik sesuai dengan } \\
\text { metode indeks biotilik }\end{array}$ & 87 & $\begin{array}{c}\text { A } \\
\text { (sangat } \\
\text { baik) }\end{array}$ \\
\hline 9 & 13 & $\begin{array}{l}\text { Mengevaluasi } \\
\text { kategori kualitas } \\
\text { perairan berdasarkan } \\
\text { indeks pencemaran air }\end{array}$ & 83 & $\begin{array}{c}\text { A } \\
\text { (sangat } \\
\text { baik) }\end{array}$ \\
\hline
\end{tabular}

Tabel 6 menunjukkan keterlibatan siswa pada kegiatan kinerja yang diobservasi di dua kelas implementasi, yaitu Kelas VII B dan Kelas VII G. Ratarata yang didapat dari sembilan kegiatan kinerja, tujuh dinyatakan dengan kriteria sangat baik, satu kegiatan kriteria baik, dan satu kegiatan kriteria cukup baik.

Persentase hasil observasi pada aspek afektif tersaji seperti pada Tabel 7 berikut.

Tabel 7 Hasil Observasi Afektif Siswa

\begin{tabular}{|c|c|c|c|c|}
\hline \multirow[b]{2}{*}{$\begin{array}{l}\mathbf{N} \\
\mathbf{0}\end{array}$} & \multirow[b]{2}{*}{$\begin{array}{l}\text { No. } \\
\text { Indik } \\
\text { ator }\end{array}$} & \multirow{2}{*}{$\begin{array}{l}\text { Aspek } \\
\text { yang } \\
\text { Diobsev } \\
\text { asi }\end{array}$} & \multicolumn{2}{|r|}{ Rata-Rata } \\
\hline & & & $\begin{array}{l}\text { Perse } \\
\text { ntase } \\
(\%)\end{array}$ & Kriteria \\
\hline 1 & 9 & Disiplin & 3,5 & $\begin{array}{l}\text { A } \\
\text { menggambarkan } \\
\text { perilaku disiplin } \\
\text { dengan tertib, patuh } \\
\text { pada berbagai } \\
\text { ketentuan peraturan } \\
\text { yang telah disepakati) }\end{array}$ \\
\hline 2 & 10 & Rasa & 4 & (sangat \\
\hline
\end{tabular}

\begin{tabular}{|c|c|c|c|c|}
\hline & & $\begin{array}{l}\text { ingin } \\
\text { tahu }\end{array}$ & & $\begin{array}{l}\text { menggambarkan } \\
\text { perilaku rasa ingin } \\
\text { tahu sehingga dapat } \\
\text { responsif, eksploratif } \\
\text { yang meluas dan } \\
\text { mendalam) }\end{array}$ \\
\hline 3 & 14 & Kreatif & 4 & $\begin{array}{lr}\text { A } & \text { (sangat } \\
\text { menggambarkan } \\
\text { perilaku } \\
\text { dengan kreatif } \\
\text { berpikir, kelancaran } \\
\text { berpikir divesan } \\
\begin{array}{l}\text { originalitas dalam } \\
\text { menghasilkan artefak, } \\
\text { elaborasi) }\end{array}\end{array}$ \\
\hline 4 & 19 & $\begin{array}{l}\text { Peduli } \\
\text { Ling- } \\
\text { kungan }\end{array}$ & 3,5 & $\begin{array}{l}\text { A } \\
\text { menggambarkan } \\
\text { perilaku peduli } \\
\text { lingkungan dengan } \\
\text { memiliki ide atau } \\
\text { tindakan mencegah } \\
\text { kerusakan pada } \\
\text { lingkungan alam } \\
\text { disekitarnya, } \\
\text { mengembangkan ide } \\
\text { atau tindakan untuk } \\
\text { memperbaiki } \\
\begin{array}{l}\text { kerusakan alam yang } \\
\text { sudah terjadi) }\end{array}\end{array}$ \\
\hline 5 & 20 & $\begin{array}{l}\text { Tang- } \\
\text { gung } \\
\text { jawab }\end{array}$ & 4 & $\begin{array}{l}\text { A } r \text { sangat } \\
\text { menggambarkan } \\
\text { perilaku tanggung } \\
\text { jawab dengan } \\
\text { mengikuti kegiatan } \\
\text { pembelajaran, } \\
\text { mengerjakan tugas, } \\
\text { membuat laporan } \\
\text { kegiatan, } \\
\text { menghasilkan artefak) }\end{array}$ \\
\hline
\end{tabular}

Tabel 7 menunjukkan perilaku siswa sangat menggambarkan pada aspek yang diobservasi, yaitu perilaku disiplin, rasa ingin tahu, kreatif, peduli lingkungan, dan tanggung jawab.

\section{Aktivitas Siswa dalam Kegiatan Pembelajaran}

Aktivitas siswa selama kegiatan pembelajaran dicatat dua orang pengamat dengan menggunakan lembar pengamatan aktivitas siswa. Pencatatan dilakukan setiap lima menit dengan melihat aktivitas yang menonjol. Rata-rata persentase aktivitas siswa di Kelas VII B dan VII G tiap pertemuan tersaji pada Tabel 8 berikut.

Tabel 8. Persentase Aktivitas Siswa

\begin{tabular}{|r|l|c|}
\hline No. & \multicolumn{1}{|c|}{ Aktivitas siswa } & Rata-rata \\
\hline 1. & Menyimak penjelasan guru. & 14 \\
\hline 2. & Membaca dan mencermati LKS. & 14 \\
\hline 3. & Mengajukan atau menanggapi & 13 \\
\hline
\end{tabular}




\begin{tabular}{|r|l|c|}
\hline & pertanyaan. & 14 \\
\hline 5. & Menulis jawaban LKS. & 15 \\
\hline 6. & $\begin{array}{l}\text { Menyiapkan prosedur eksperimen } \\
\text { yang diberikan guru pada LKS. }\end{array}$ & $\begin{array}{l}\text { Melibatkan diri secara aktif untuk } \\
\text { mengumpulkan data dengan } \\
\text { menggunakan prosedur percobaan } \\
\text { yang diberikan guru pada LKS. }\end{array}$ \\
\hline 7. & $\begin{array}{l}\text { Melibatkan diri secara aktif untuk } \\
\text { menganalisis data } \\
\text { merumuskan simpulan. }\end{array}$ & 16 \\
\hline 8. & $\begin{array}{l}\text { Melibatkan diri secara aktif untuk } \\
\text { mempresentasikan hasil kegiatan. }\end{array}$ & 13 \\
\hline 9. & $\begin{array}{l}\text { Melibatkan diri dalam kegiatan } \\
\text { diskusi dan persiapan pameran di } \\
\text { kelas. }\end{array}$ & 13 \\
\hline 10. & Kegiatan yang tidak relevan. & 1 \\
\hline PERSENTASE RELIABILITAS (\%) & 78 \\
\hline
\end{tabular}

Tabel 8 menunjukkan bahwa keterlibatan siswa pada kegiatan pembelajaran di dua kelas implementasi cukup tinggi, sedangkan aktivitas siswa yang tidak relevan dengan kegiatan pembelajaran mempunyai persentase yang sangat rendah. Sepuluh aktivitas siswa pada tiap-tiap pertemuan mempunyai reliabilitas sebesar 78\% yang berarti instrumen ini dapat dikategorikan instrumen yang baik, dengan hasil pengukuran yang dapat dipercaya.

\section{Respon Siswa terhadap Kegiatan Pembelajaran}

Untuk mengetahui respon siswa terhadap seluruh kegiatan pembelajaran, penulis menggunakan angket siswa yang disebarkan setelah proses pembelajaran berakhir. Analisis data hasil rekapitulasi persentase respon siswa terhadap komponen pembelajaran model guided discovery berbasis kegiatan biomonitoring partisipatif yang dilakukan pada dua kelas implementasi dapat dilihat pada Tabel 9 berikut.

Tabel 9. Persentase Aktivitas Siswa

\begin{tabular}{|c|c|c|c|c|}
\hline No. & \multicolumn{2}{|c|}{ Respon siswa } & \multicolumn{2}{|c|}{$\begin{array}{l}\text { Persentase } \\
\text { Rata-rata } \\
(\%)\end{array}$} \\
\hline \multirow{8}{*}{1.} & \multicolumn{2}{|c|}{$\begin{array}{l}\text { Bagaimana pendapat Anda } \\
\text { tentang komponen berikut ini? }\end{array}$} & $\mathbf{T}$ & TT \\
\hline & a. & Tema yang dipelajari & 88 & 12 \\
\hline & b. & Materi Ajar Siswa & 88 & 12 \\
\hline & c. & $\begin{array}{l}\text { Lembar Kegiatan Siswa } \\
(\mathrm{LKS})\end{array}$ & 93 & 7 \\
\hline & d. & $\begin{array}{l}\text { Pembelajaran model guided } \\
\text { discovery berbasis kegiatan } \\
\text { biomonitoring partisipatif }\end{array}$ & 98 & 2 \\
\hline & e. & Cara guru mengajar & 92 & 8 \\
\hline & f. & Suasana belajar di kelas & 92 & 8 \\
\hline & g. & $\begin{array}{l}\text { Kegiatan kinerja di } \\
\text { lapangan atau laboratorium }\end{array}$ & 98 & 2 \\
\hline
\end{tabular}

\begin{tabular}{|c|c|c|c|c|}
\hline \multirow{8}{*}{2.} & \multicolumn{2}{|c|}{$\begin{array}{l}\text { Apakah anda merasa komponen- } \\
\text { komponen berikut ini sebagai hal } \\
\text { baru? }\end{array}$} & \multirow{2}{*}{$\begin{array}{l}\text { B } \\
85\end{array}$} & \multirow{2}{*}{$\begin{array}{r}\text { BB } \\
15\end{array}$} \\
\hline & a. & Tema yang dipelajari & & \\
\hline & b. & Materi Ajar Siswa & 98 & 2 \\
\hline & c. & $\begin{array}{l}\text { Lembar Kegiatan Siswa } \\
\text { (LKS) }\end{array}$ & 98 & 2 \\
\hline & d. & $\begin{array}{l}\text { Pembelajaran model guided } \\
\text { discovery berbasis kegiatan } \\
\text { biomonitoring partisipatif }\end{array}$ & 100 & 0 \\
\hline & e. & Cara guru mengajar & 100 & 0 \\
\hline & f. & Suasana belajar di kelas & 86 & 14 \\
\hline & g. & $\begin{array}{l}\text { Kegiatan kinerja di } \\
\text { lapangan atau laboratorium }\end{array}$ & 90 & 10 \\
\hline \multirow{7}{*}{3.} & \multicolumn{2}{|c|}{$\begin{array}{l}\text { Apakah anda merasa mudah } \\
\text { untuk memahami komponen- } \\
\text { komponen berikut ini? }\end{array}$} & $\mathbf{M}$ & $\mathbf{S}$ \\
\hline & a. & Tema yang dipelajari & 86 & 14 \\
\hline & b. & Materi Ajar Siswa & 92 & 8 \\
\hline & c. & Contoh-contoh soal & 88 & 12 \\
\hline & d. & $\begin{array}{l}\text { Lembar Kegiatan Siswa } \\
\text { (LKS) }\end{array}$ & 95 & 5 \\
\hline & e. & $\begin{array}{l}\text { Pembelajaran model guided } \\
\text { discovery berbasis kegiatan } \\
\text { biomonitoring partisipatif }\end{array}$ & 91 & 9 \\
\hline & f. & Cara mengajar guru & 95 & 5 \\
\hline & & Apakah anda berminat jika: & BM & TB \\
\hline 4. & & $\begin{array}{l}\text { Kegiatan pembelajaran } \\
\text { yang digunakan guru saat } \\
\text { ini diterapkan pada topik- } \\
\text { topik pembelajaran yang } \\
\text { lain }\end{array}$ & 87 & 13 \\
\hline
\end{tabular}

Keterangan:

$$
\begin{array}{ll}
\mathrm{T}=\text { tertarik } & \mathrm{B}=\text { baru } \\
\mathrm{TT}=\text { tidak tertarik } & \mathrm{BB}=\text { bukan hal } \\
\text { baru } \mathrm{S}=\text { susah } & \\
\mathrm{TB}=\text { tidak berminat } &
\end{array}
$$

Tabel 9 menunjukkan bahwa sebagian besar siswa di Kelas VII B dan Kelas VII G menunjukkan ketertarikan, kebaharuan, kemudahan dan keberminatan terhadap seluruh komponen yang ada pada kegiatan pembelajaran model guided discovery berbasis kegiatan biomonitoring partisipatif. Dengan respon tersebut, maka perangkat pembelajaran yang dikembangkan penulis dapat diimplementasikan lebih lanjut pada pembelajaran IPA.

\section{Kendala-kendala Dalam Pembelajaran}

Kendala-kendala yang ditemui selama kegiatan pembelajaran adalah sebagai berikut. Kendala pertama, siswa belum pernah melakukan pembelajaran model guided discovery berbasis kegiatan biomonitoring partisipatif. Adanya kendala tersebut dapat menyebabkan tidak tercapainya tujuan hasil belajar yang ingin dicapai pada penelitian ini. Menyikapi kendala tersebut, penulis memilih solusi alternatifnya 
dengan melakukan simulasi sebelum kegiatan pembelajaran berlangsung. Kegiatan simulasi sekaligus dapat membantu memudahkan siswa dalam mengimplementasikan pendekatan saintifik.

Kendala selanjutnya yang didapati yaitu, di awal kegiatan pembelajaran siswa merasa kesulitan dalam merumuskan definisi operasional variabel. Untuk itu guru perlu lebih membimbing siswa dalam merumuskan definisi operasional variabel melalui kegiatan pembelajaran dengan pendekatan metode ilmiah. Kendala ketiga yaitu pada keefektifan waktu pembelajaran di RPP 02 yang kurang baik, dan siswa belum terbiasa dengan kegiatan eksperimen di lapangan maupun di laboratorium dengan pendekatan sains. Hal ini terjadi dikarenakan pembelajaran IPA yang selama ini dilakukan belum mengarah kepada pendekatan sains, sehingga masih perlu menyesuaikan diri dalam belajar. Solusi alternatifnya adalah senantiasa mengingatkan efektifitas penggunaan waktu, dan membiasakan siswa dalam kegiatan pembelajaran dengan pendekatan sains. Di hari selanjutnya efektivitas waktu sudah tidak menjadi hambatan, hal ini ditunjukkan dengan ketepatan waktu dalam pelaksanaan pembelajaran.

Siswa yang belum terbiasa melakukan eksperimen dengan alat dan bahan seperti yang tersebut dalam LKS juga merupakan kendala yang harus dicari pemecahannya. Solusi alternatifnya adalah sebelum kegiatan eksperimen dimulai, guru memperkenalkan alat dan bahan berikut cara penggunaannya, selanjutnya membimbing siswa dalam pemakaian alat dan bahan. Kendala terakhir yaitu lokasi eksperimen di lapangan berupa anak sungai, sehingga perlu kehati-hatian dalam pengambilan sampel. Solusi alternatifnya adalah senantiasa mengingatkan siswa untuk berhati-hati, dan melakukan pengawasan dengan ketat.

Konsep pembelajaran berbasis sains menyebabkan siswa dididik dan dilatih agar terampil dalam mencari tahu tentang alam secara sistematis untuk menguasai pengetahuan, fakta-fakta, konsep-konsep, prinsipprinsip, proses penemuan, dan memiliki sikap ilmiah (Putra, 2013). Selama guided discovery, guru masih perlu memberikan susunan dan bimbingan untuk memastikan bahwa abstraksi yang sedang dipelajari sudah akurat dan lengkap (Eggen \& Kauchak, 2009), guru memainkan peran yang lebih aktif, dengan memberikan petunjuk, menata bagian-bagian kegiatan, atau memberi garis besar (Slavin, 2011). Heong, 2011(b) dalam penelitiannya menyatakan bahwa siswa harus dibantu untuk memperoleh keterampilan berpikit tingkat tinggi, baik dengan pembelajaran maupun lingkungan.

\section{KESIMPULAN}

\section{A. Simpulan}

Berdasarkan temuan-temuan pada pelaksanaan implementasi terhadap perangkat pembelajaran yang dikembangkan, disimpulkan bahwa pengembangan perangkat pembelajaran model guided discovery berbasis kegiatan biomonitoring partisipatif memiliki kelayakan, kepraktisan, dan efektivitas yang baik sehingga dapat digunakan dan dapat meningkatkan keterampilan berpikir tingkat tinggi siswa pada materi pencemaran air.

\section{B. Saran}

Adapun saran yang diajukan berdasarkan penelitian yang telah dilakukan dan temuan-temuan yang diperoleh pada Uji Coba I (uji coba pada kelas terbatas) adalah sebagai berikut.

a. Perlunya kegiatan simulasi sebelum kegiatan pembelajaran berlangsung, agar efektivitas pembelajaran dapat terlaksana dengan baik.

b. Perlunya bimbingan yang lebih intensif dalam merumuskan definisi operasional variabel melalui kegiatan pembelajaran dengan metode ilmiah.

c. Perlunya pembiasaan pendekatan sains pada siswa, agar siswa terbiasa melakukan kegiatan pembelajaran dan eksperimen untuk menyelesaikan suatu masalah, menyampaikan pendapat seluasluasnya, melakukan asesmen, dan berkreasi.

d. Perlunya keuletan, kesabaran dan kreativitas yang tinggi untuk mengoptimalkan logistik pendukung, sehingga penggunaan alat dan bahan yang belum dikenal oleh siswa dapat optimal.

Perlunya kehati-hatian dan pengawasan yang ketat pada pelaksanaan kegiatan eksperimen lapangan, jika lokasi eksperimen lapangan pada materi pencemaran air berupa anak sungai.

\section{REFERENSI}

Achmad, R. (2004), Kimia Lingkungan, Jakarta: Universitas Negeri Jakarta- Penerbit ANDI.

Affandi, M., (1997), "Spesies Indikator dalam Lingkungan". Makalah disajikan pada Pendidikan Dasar Pengenalan Lingkungan UNAIR-PPLH Seloliman, Surabaya.

Aiken, L. R (1997). Psychological Testing and Assessment Ninth Edition, New York: Mc. Graw-Hill Company.

Alfieri, L., et al. (2009). "Does Discovery-Based Instruction Enhance Learning?". Journal of Educational Psychology American Psychological Association 2011. Vol. 103 No. 1 pp. 1-18. 
Alland, J. D. (1995). Stream Ecology Structure and Function of Running Waters. London: Chapman and Hall.

Anderson, L. W., \& Krathwohl, D. R. (2001). A Taxonomy for Learning, Teaching, and Assessing: A Revision of Bloom's Taxonomy of Educational Objectives. NY: Addison Wesley Longman.

Arends, R. I. (2007). Learning To Teach. New York: McGraw Hill Companies, Inc.

Arifin, Z. (2013). Evaluasi Pembelajaran. Bandung: Remaja Rosdakarya.

Arikunto, S. (2010). Prosedur Penelitian Suatu Pendekatan Praktik, Jakarta: Rineka Cipta.

Azhar, A. (1997). Media Pembelajaran. Jakarta: PT Raja Grafindo Perkasa.

Borich, G. D. (1994). Observation Skills for Effective Teaching, New York: Macmillan Publishing Company.

Campbell, N. A., \& Reece, J. B. (2010).Biology Jilid 1., Jakarta: Penerbit Erlangga.

Carin, A. A. (1993). Teaching Science Through Discovery. New York: Mcmillan Publishing Company.

Collette, A. T., \& Chiapetta, E. L. (1994). Science Instruction in The Middle and Secondary Schools. New York: Macmillan Publishing Company.

Costa, L., Arthur. (1988). Developing Minds, Virginia: ASCD.

Dahar, R. W. (1988). Teori-teori Belajar, Jakarta: P2LPTK Direktorat Jendral Pendidikan Tinggi Depdikbud.

Depdiknas. (2006). Peraturan Menteri Pendidikan Nasional Nomor 22 Tahun 2006 tentang Standar Isi untuk Satuan Pendidikan Dasar dan Menengah. Jakarta: Depdiknas.

Depdiknas, (2007). Peraturan Menteri Pendidikan Nasional Nomor 41 Tahun 2007 tentang Standar Proses untuk Satuan Pendidikan Dasar dan Menengah. Jakarta: Depdiknas.

Effendi, Leo Adhar. (2012). "Pembelajaran Matematika Dengan Metode Penemuan Terbimbing Untuk Meningkatkan Kemampuan Representasi Dan Pemecahan Masalah Matematis Siswa SMP”., Jurnal UPI. Vol. 13 No.2 Oktober 2012.

Eggen, P., \& Kauchak, D. (2012). Strategies and Models for Teachers: Teaching Content and Thinking Skills, $6^{\text {th }}$ Editio. Boston: Pearson Education Inc.

Ennis, R. H. (1996). Critical Thinking. New Jersey: Prentice-Hall, Inc.

Fardias, S. (1992). Polusi Air dan Udara, Bogor: Penerbit Kanisius.
Fisher, A.. (2007) Critical Thinking: An Introduction., UK: Cambridge University Press.

Greenberg A. E., J. J. Connor \& D. Jenkins. (1981), Standard Methods for The Exam. Washington DC: Nation of Water and Health Association.

Grondlund, N. E., \& Linn, R. L. (1985). Measurement and Evaluation in Teaching, New York: McMillan Publishing Company.

Hake, R. R. (1998). "Interactive-engagement versus traditional methods: a six thousand student survey of mechanics test data for introductory physics courses. Department of physics, Indiana University, Bloomington", http://www.physics.indiana.edu/sdi/analyzingc hange-gain.pdf.

Handogo \& Razif. (1996). "Kesiapan IPTEK dalam Pengelolaan Lingkungan Hidup", Makalah disajikan pada Konferensi Nasional XIII PSL, Denpasar, Bali.

Hamalik, O. (2012). Psikologi Belajar dan Mengajar, Bandung: Penerbit Sinar Baru Algensindo.

Hasibuan, et al. (2012). "Analisis Pembelajaran Guided Discovery Dengan Menggunakan Macromedia Flash Dikaitkan Dengan Kecerdasan Logik Matematik Terhadap Hasil Belajar Fisika Siswa SMAN 1 Kota Subulussalam”, Jurnal Penelitian Inovasi Pembelajaran Fisika UNIMED Vol. 4.2 (2012): 20-25.

Hawkes, H. W. (1979). Invertebrates as Indicator of River Water Qualit. Chechester: John Wiley and Sons.

Heong, et al. (2011) "The Perception of The Level of Higher Order Thinking Skills Among Technical Education Students, Faculty of Technical Education University Tun Hussein Onn Malaysia Johor". Journal International Conference on Social Science and Humanity IPEDR. Vol.5 IACSIT Press, Singapore.

Ibrahim, M. (2005). Assesmen Berkelanjutan, Surabaya: Unesa Press.

Ibrahim, M. (2010). Dasar-dasar Proses Belajar Mengajar, Surabaya: Unesa Press.

Iskandar, J. (2009). Ekologi Manusia dan Pembangunan Berkelanjutan. Bandung: Program Studi Magister Ilmu Lingkungan Universitas Padjajaran.

Jacobsen, D. A. et all. (2009). Methods For Teaching: Promoting Student Learning in K-12 Classrooms, New Jersey: Pearson Education, Inc.

Joyce, W., et all. (2009). Models of Teaching $4^{\text {th }}$ ed, Needham Heights: Allyn and Bacon 
Kardi, S. (2013). Tujuan Pembelajaran Perumusan dan Penggunaannya, Surabaya: Program Pascasarjana UNESA

Kheng, Y. T. (2008) Science Process Skills Form 2., Selangor: Longman Pearson Malaysia Sdn. Bhd.

Khaerudin, \& Sujiono, E. H. (2005). Pembelajaran Sains (IPA) Berdasarkan Kurikulum Berbasis Kompetensi. Makassar: Badan Penerbit UNM.

Krathwohl, D. R. (2002). "A Revision of Bloom's Taxonomy: An Overview". Theory Into Practice, Vol 41 No. 4 Autumn 2002, pp. 212 $-218$.

Langer, E. J. (2008) The Power of Mindful Learning, US: Perseus Books, Inc.

Lie, A. (2008) Cooperative Learning Mempraktikkan Cooperative Learning di Ruang-ruang Kelas. Jakarta: PT Gramedia

Lissa, et al. (2012). "Pengembangan Instrumen Penilaian Keterampilan Berpikir Tingkat Tinggi Materi Sistem Respirasi dan Ekskresi”, http://journal.unnes.ac.id/nju/index.php/LIK.

Manahan, Stanley E. (1994). Environmental Chemistry, Boston: Lewis Publisher.

Mason, C. F. (1991). Biology of Fresh Water Pollution, Second Edition. London: Longman.

Mayer, R. (2008). Learning and Instruction. Upper Saddle River, NJ: Pearson

Michael. (1994). Metode Ekologi Untuk Penyelidikan Lapangan dan Laboratorium. Jakarta: Penerbit Universitas Indonesia.

Moreno, R., \& Duran, R. (2004). "Do Multiple Representations Need Explanation". Journal of Educational Psychology. Vol. 96.

Mulyasa. (2007). Kurikulum Tingkat Satuan Pendidikan, Bandung: Remaja Rosdakarya.

Nasihah, M. (2012). Pengembangan Perangkat Pembelajaran Pendidikan Lingkungan Hidup Berorientasi Penemuan Terbimbing (Guided Discovery) di FKIP Unisda Lamongan (Tesis Magister Pendidikan tidak dipublikasikan). Universitas Negeri Surabaya.

Nasution, S. (2003). Berbagai Pendekatan dalam Proses Belajar dan Mengajar. Jakarta: PT Bumi Aksara

Norish, R. H., \& Norish K. R. (1995). "The Need for Biological Assessment of Water Quality : Australian Perspective". Australian Journal of Ecology Vol. 20, 1-6.

Nur, M. (1998). Teori Pembelajaran Kognitif. Surabaya: Unesa Press.

Nur, M. (2008). Pengajaran Berpusat kepada Siswa dan Pendekatan Konstruktivis dalam Pengajaran, Edisi 5. Surabaya: Pusat Sains dan Matematika Sekolah Universitas Negeri Surabaya.

Nur, M. (2011). Modul Keterampilan-keterampilan Proses Sains. Surabaya: Pusat Sains dan Matematika Sekolah Universitas Negeri Surabaya.

Odum, E. P. (1993). Dasar-dasar Ekologi (Terjemahan Tjahyono Samingan). Yogyakarta: Gadjah Mada University Press.

Ompusunggu. (2003), Intisari Pelajaran Biologi Untuk SLTP Kelas 1, Bandung: Yrama Widya.

Pemerintah Propinsi Daerah Tingkat 1 Jawa Timur. (2000). Buku 1 Analisis Kebijakan Prokasih 2000. Jawa Timur: Pemprop Jatim.

Prasetyo, A. B. (2000). Penanganan Limbah, Surabaya: Universitas Airlangga.

Prastowo, A. (2012). Panduan Kreatif Membuat Bahan Ajar Inovatif. Yogyakarta: Diva Press.

Purwanto. (2012). "Penerapan Model Pembelajaran Guided Discovery pada Materi Pemantulan Cahaya untuk Meningkatkan B erpikir Kritis". http://journal.unnes.ac.id/sju/index.php/upej.

Putra, S. R., (2013). Desain Belajar Mengajar Kreatif Berbasis Sains. Jogjakarta: Diva Press

Rahmawati. (2012). "Pengembangan Perangkat Pembelajaran dengan Metode Pembelajaran Penemuan Terbimbing (Guided Discovery) untuk Melatih Keterampilan Berpikir Kritis Siswa SMP", Tesis Magister Pendidikan, Universitas Negeri Surabaya.

Ramos, et al. (2013). "Higher Order Thinking Skills and Academic Performance in Physics of College Students: A Regression Analysis, Philippines Benguet State University". International Journal of Innovative Interdisciplinary Research Issu. Vol. 4.

Ratumanan, T. G., \& Laurens, T.___. Penilaian hasil Belajar pada Tingkat Satuan Pendidikan, Surabaya: Unesa Press.

Resh, V. H. (2010) .Panduan Biotilik untuk Pemantauan Kesehatan Daerah Aliran Sungai. Gresik : Ecoton-Inspirasi-Kementrian LH RI.

Rini D. S. (2007). Panduan Lapangan Makroinvertebrata Kali Surabaya untuk Penilaian Kualitas Air., Gresik : Ecoton..

Riyanto, Y. (2012). Paradigma baru Pembelajaran, Jakarta: Kencana Prenada Media Grup.

Rohman, M., \& Amri, S. (2013). Strategi dan Desain Pengembangan Sistem Pembelajaran, Jakarta: Prestasi Pustakaraya.

Rosenbergh, D. M., \& Resh, V. H. (1993) Freshwater Biomonitoring and Benthic 
Macroinvertebrates. London: Chapman and Hall.

Rusman. (2010). Model-model Pembelajaran Mengembangkan Profesionalisme Guru. Jakarta: Raja Grafindo Persada.

Sanjaya, W. (2011). Strategi Pembelajaran Berorientasi Standar Proses Pendidikan. Jakarta: Kencana Prenada Media.

Sastrawijaya, A. T. (1991). Pencemaran Lingkungan., Jakarta: Penerbit Kineka Cipta

Slavin, R. E. (2009). Educational Psychology: Theory and Practise, $9^{\text {th }}$ ed. New Jersey: Pearson Education, Inc.

Smith, M. K., et al. (2009). Teori Pembelajaran dan Pengajaran. Jogjakarta: Mirza Media Pustaka.

Soegianto, A. (1993). Ekosistem Darat dan Perairan Tawar. Surabaya: KLH-ITS dan Bapeda.

Sudaryanti. (1997). Strategi Pemantauan Kualitas Air Sungai Secara Biologis, Malang: Universitas Brawijaya.

Sudaryono, et al. (2012). Pengembangan Instrumen Penelitian Pendidikan, Yogyakarta: Graha Ilmu.

Sudjana. (2005). Metoda Statistika. Bandung: Tarsito.

Sudijono, A. (2011). Pengantar Evaluasi Pendidikan, Jakarta: Raja Grafindo Perkasa.

Sugiyono. (2010). Metoda Penelitian Kuantitatif dan Kualitatif $R \& D$. Bandung: Alfabeta.

Suratmo, G. F. (1996). Permasalahan Lingkungan Hidup dalam Tinjauan Pengertian Konsepkonsep Ekologi (Makalah disajikan pada
Konferensi Nasional XIII PSL.) Denpasar, Bali.

Suryabrata, S. (2006). Psikologi Pendidikan. Jakarta: PT RajaGrafindo Persada.

Suyono, \& Hariyanto (2011). Belajar dan Pembelajaran Teori dan Konsep Dasar. Bandung: Rosdakarya.

Tanjung, H. S. D., \& Tanjung, S. D. (1996). Prospek Penggunaan Bioindikator dalam Evaluasi Kualitas Lingkungan Perairan. Yogyakarta: UGM.

Thiagarajan, S. (1974). Instructional Development for Training Center of Exceptional Children. Minepolish: Indiana University.

Toharuddin, U., et al. (2011). Membangun Literasi Sains Peserta Didik. Bandung: Humaniora.

Trihadiningrum. (1997). Penggunaan Makro Invertebrata sebagai Bioindikator Tingkat Sanitasi di Hulu Sungai Brantas. Surabaya: Fakultas Teknik Lingkungan Institut Teknologi Sepuluh Nopember.

Wasis, Irianto, S. Y. (2008). BSE, Jakarta: Pusat Perbukuan Depdiknas.

Welch, E. B. (1992). Ecological Effects of Wastwater, Second Edition, London: Cambridge University Press.

Widiantini, T. (2013). Artikel Penyusunan LKS sebagai Bahan Ajar. Yogyakarta.

Winkel, W. S. (1999). Psikologi Pengajaran. Yogyakarta: Grasindo. 